\title{
Talent Management Strategies and Employee Performance in the National Police Service, a Case Study of Nairobi City County Kenya
}

\author{
Kangogo Kemboi Reuben \\ Department of Security and Correctional science \\ Kenyatta University. \\ Dr. Sirera Merecia \\ Department of Security and Correctional science \\ Kenyatta University.
}

\begin{abstract}
The success of every organization is dependent on the strategies put in place to acquire, grow, and retain top talent to enhance employee performances. Today's greatest challenge faced by managers in the wake of globalization, developing technology and workforce diversity is competition for talented employees which has increased considerably. These emerging trends have led organizations focus on effective strategies for talent management. The aim of this study was to establish the effect of talent management strategies on performance of National Police Service officers in Nairobi County. This study focused on establishing the effects of performance appraisal on employee performance in the National Police Service within Nairobi County. The study was underpinned by the Talent-Based Theory. This study embraced descriptive survey research design in which Yamen's formula for sample size determination was used to arrive at a sample of 351 respondents. The study adopted questionnaires and interviews as the research instruments for data collection. The study questionnaire was tested for validity by doing a pretest, thus content and criterion validity that informed refinement of the items to enhance validity. Reliability of the questionnaire was ascertained using test-retest method where Cronbach's Alpha coefficient of reliability was computed. Data collected was analyzed using the Statistical Package for the Social Sciences (SPSS) Version 23.0 for windows. Both Descriptive and inferential statistics were analyzed in the study. The findings of the study revealed a statistically significant relationship between performance appraisal and employee performance in the National Police Service in Nairobi County to the extent that a unit change in performance appraisal practices resulted in 0.772 unit change in employee performance in the National Police Service in Nairobi County, Kenya. The study recommended that talent management practices should be emphasized as doing so brings about superior organizational performance.
\end{abstract}

Key words: Talent Management, Performance Appraisal, Employee Performance, National Police Service

DOI: $10.7176 /$ PPAR/11-4-06

Publication date:May $31^{\text {st }} 2021$

\subsection{Background of the Study}

In today's competitive business environment characterized by uncertainty and complexity; talent management strategy is key a differentiator for an organizational success (Ratna, 2016). The advent of globalization, changing demographics and improved technology has compelled organizations to design talent management strategies that fit their national context (Asava, 2019). Respective entities must draw, empower and keep their competent staffs for growth and continuity (Ling \& Jaw, 2017).

The performances of organizations globally rely on the firm capability to put strategies in place to make sure that competent personalities with appropriate expertise are in the right place at the right time, and focused on needful tasks. This has made many Human resource practitioners elevate talent management to the highest priority across all organizations (Asava, 2019). organizations have currently regarded talent management with higher esteem for the best competitive advantage and superior performance (Moore, 2017). Competent talents are a must have for any entity. Ideally, the single most important function of human resources is ensuring that the staffs acquire relevant skills, while exhibiting loyalty to the firm (Njiru, 2018). 
According to Wright and Geroy, (2018) talent is the natural capability of a person to discharge his duties in a unique manner. Talent ideally is a person's abilities, including and not limited to gifts, proficiency, comprehension, experience, intellect, opinion, attitude, personality, and drive. Snell (2017) referred to talent management as a process, entailing complete and comprehensive firm activities like spotting new talents, selecting, empowering and retaining the highly performing staffs while empowering them for future top leaderships, plus guiding them in embracing the best use of strengths for full engagement, hence maximum performance of the firm (Ling \& Jaw, 2017).

Performance appraisal is a talent management and organizational assessment tool which aids the leadership to monitor and assess the work of the subordinates. The main objective of performance appraisal is to embrace a friendly environment for best performance for the highest-quality work most efficiently and effectively (Rastgoo, 2016). Managers and supervisors in the National Police Service use performance appraisal tools to moderate the available tasks, advice for remedies, and make other decisions which can help officers exceed the preset objectives. This in some way guides the organization achieves its mission and performs well (Ratna et al., 2016). For example, the officer in charge of a station can recommend a junior officer for a more detailed duty. The officer assigned will then have to exploit all possibilities to optimally perform the task that will maybe culminate into a promotion or just a reward. The National Police Service do have a Performance appraisal system where the officers in charge are mandated to offer possible guidance and/or support like proposing a training and development course or promising the officer a reward of any kind. This definitely drives officers to exploit all individual potentials to succeed in assigned tasks. However, despite the existence of this strategy, it is still not clear how this talent management strategy influences the ultimate performance of the officers in the National police service.

Chepkwony (2018) found out that talent management is an ingredient to employee performance, although his study primarily the study focused on coaching and mentoring ignoring other measures of talent management like performance appraisal, compensation, and succession planning among many. On the other hand, Dechev, (2017) asserts that talent management highly influence employee performance in the insurance sector, but didn't examine the variables of talent management. Management of talents is instrumental for bolstering employee performance, when an organization embraces compensation, performance appraisal, succession planning, training and development among others in their Human Resource function. Studies on talent management and employee performance points out, that some of their constructs have been examined. However, talent management on employee performance has largely been neglected in these literatures in terms of both theory and evidence. Nonetheless, a handful of relevant case studies and surveys exists, a few of which has been hypothesized. Hence this study sought to determine the effect of talent management strategies on performance of National Police Service officers in Nairobi County

\section{2: Statement of the Problem}

In this era of worldwide business operations, talent management is very vital for any organization that focuses on growth. Talent management and its dimensions have some impact on employee's performance. Although the National police service has put in place strategies on compensation, training and development, succession planning and performance appraisal of officers, little is known on how these strategies affect the performance of the officers. The aim of this study therefore, was to establish the effect of talent management strategies on employee performance in the National Police Service where performance appraisal was adapted as a talent management tool. Studies conducted on talent management in Kenya, have however majorly focused on corporate organizations with little attention on the public sector particularly the National Police service hence this study sought to fill the existing knowledge gap.

\subsection{Research Objective}

To establish the effect of performance appraisal on performance of National Police Service officers within Nairobi County

\subsection{Research Questions}

How does performance appraisal affect performance of National Police Service officers within Nairobi County?

\subsection{Literature Review}

This section focused on theories underpinnings as well as a review of empirical literature for the study. 


\subsubsection{Theoretical Framework}

A theory is a system of explaining phenomena by stating concepts from variables and the laws that make them interdependent. A concept, abstraction or idea is normally drawn from the specific objectives of a research study (Mugenda \& Mugenda, 2018). This study was pegged on talent-based theory.

\subsubsection{Talent-Based Theory}

The proponent of this theory is Roberts (2008). This theory of the firm opines that talent is the only particular resource which offers sustainable competitive advantage; hence organizations must put focus on attracting and maintaining the talented workforce. It reinforces the need for an organization to invest in talent development to continuously increase value in its people performance. An organization which develops talents is the one which cares for the organizational productivity.

This theory is applicable to the study as it ropes in talent management in the National Police Service. Talentbased theory of the organization holds that talent is the single best resource that gives excellent edge to an entity, thus, the National Police Service' focus should be tailor made on managing available talents plus the cutthroat potentials received there from. Talent is not seen as something above-average, but something that fits well certain expectations. An organization which develops talents is the one which cares for the organizational culture development and simultaneously has the results of it, as probably the employees who are talented have opportunities there for self-realization. The processes are the determinants for success should arise so that the individuals indeed want to give everything of themselves of what is possible to offer and even more

\subsubsection{Performance Appraisal Strategy}

Complexity in the business world has led to the emergence of new and comprehensive concepts in managing business. Performance appraisal is an idea in the field of managing human resources which is a continuous process of sourcing, evaluating and empowering individual worker performance and supporting the ultimate performance with the firm's strategic goals (Ingram, 2016). Performance management has been severally confused with performance appraisal but the latter is a portion of the prior. (Kleiner, 2017).

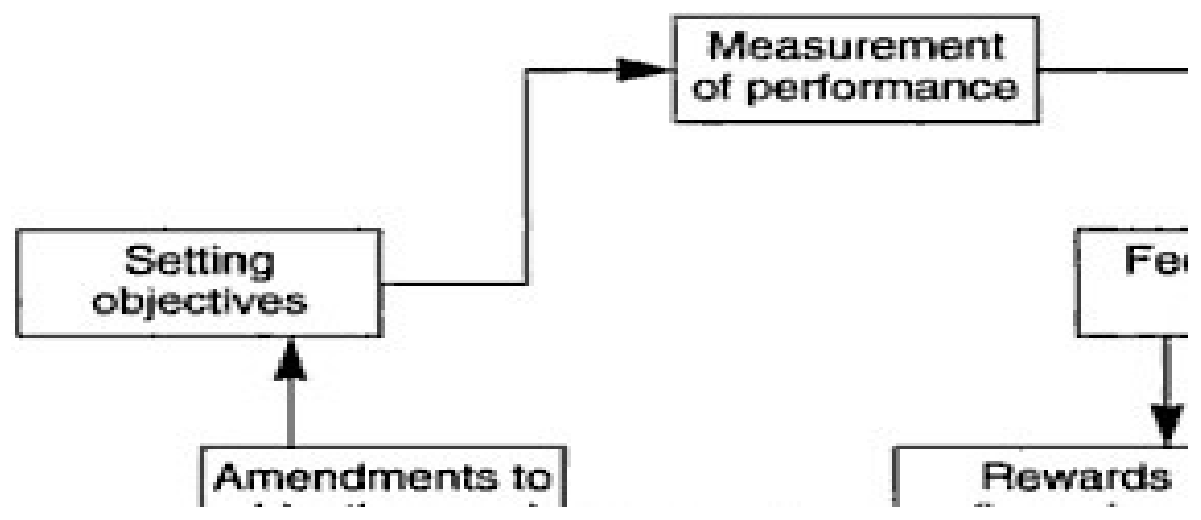

Source: (Kleiner, 2017).

Every other employee would aspire to do well in their assigned tasks. By doing so, one preset target needs to be clear, and a worker ideally requires training and development to meet or exceed the targets (Mutunga, 2019). Performance appraisal cannot just be an annual event but an incessant, constructive group effort between immediate supervisor and employee. This then calls for a close coordination between the supervisor and subordinate all through, for possible modifications to the evaluations while the boss can assess the later on his or her productivity and advice on best course of action (Ng'ethe et al., 2017)

A good majority of employees do not prefer the one-on-one performance sharing with their bosses. But remember that the supervisor would always want the subordinate to succeed on his tasks (Moore, 2017). If both parties have been communicating openly and frequently all year round, nothing in the evaluation should come as a surprise. The employee is supposed to inquire from the supervisor if he or she may revise the documented results on his performance just before the meeting. This gives the former time to consider the feedback and gather own thoughts before talking in person with the supervisor. At the National Police Service, the subordinate 
employee does have the mandate to give personal views prior to the documented assessment is completed. After holding dialogue and discussion amongst the two, they both have to sign the form and the evaluation result is stored in the departmental personnel file for some time before another evaluation is done (Dechev, 2017).

A passionate, self-driven, and competent labor force are the main drivers of higher progression in any entity, but establishing avenues of sourcing and maintaining competent workforce isn't a walk in the park (Esu, 2019). Implementing performance appraisal systems at the National Police Service will definitely lead to higher productivity from the workforce, however, this calls for embracing and implementing talent management in order to drive organizational growth (Dechev, 2017). Put simply, employee engagement involves building the National Police Service environment where all parties, from junior officers to senior police officers, are nurtured motivated for best performance. Embracing maximum employee engagement will allow NPS as a whole excellent chance to develop and expand over time (Javed \& Hussain, 2017).

Moore, (2017) argued that an organization cannot acquire excellent results by establishing and budgeting various approaches to manage talent alone. They have to be implemented amongst the employees and practiced over and over. Notably the National Police Service have a performance appraisal strategy for talent management which is aligned with its vision, however little is known on how this has affected officer's performance hence need for this study.

\subsection{Research Methodology}

The study adopted descriptive survey research design for a detailed provision of a structure to evaluate the situation as it is tendency and state of affairs in the National police Service officers within Nairobi County. Descriptive survey design provided the Researcher with a position to better comprehend the issues to do with the possible attitudes, values. behavior among other characteristics of the target population who are officers within Nairobi County. This enabled the researcher to collect original data from the population hence saving time and resources.

The target population for this study involved officers from the National Police Service across all the ranks of commissioner of police-to-police constables within Nairobi County. According to the National Police Service Human Resource Records (2020), there are about 2883 police officers under various sub-County Police commands within Nairobi County.

This study utilized Multi-stage sampling to draw the sample size from the targeted population. First, every sub county acted as a stratum. From every sub county (stratum) simple Stratified random sampling method was utilized to select participants from the various ranks. This was preferred since it ensured that each unit with the target population had equal representation chances as well as independent opportunity of forming part of the sample. Yamane's formula (1967) was utilized to determine the sample size.

The study used self-structured questionnaires and interview guides to gather information from the sampled population. The study embraced structured questions for standardized questionnaires to all the respondents and were distributed to the officers and collected immediately they completed filling them. Questionnaires enabled the researcher to reach a representative number of respondents with ease. Questionnaires thus gathered more information at a faster rate than the interview guides. Questionnaires also enabled the researcher collect information of personal views, feelings and hence disqualifying subjectivity.

However, Gazzeted officers were interviewed using a set of questions in the interview schedule. This enabled the researcher receive a more detailed feedback with personal feelings, opinions and perceptions. Interviews gave the advantage of probing the respondents further to get objective and comprehensive responses while recording their own words.

Data collected from the field were analyzed using descriptive and inferential statistics. Descriptive statistics involved the use of frequency, means, standard deviation to assess the measures of central tendency for each of the study variables and also the measures of dispersion for each variable. Data were analyzed with the aid of the Statistical Package for Social Sciences (SPSS) version 23 for windows. All statistical measures were performed within $95 \%$ confidence interval.

\subsection{Study Findings}

Study findings are presented in this section; 


\subsubsection{Response Rate}

The study collected data through a questionnaire distributed to a targeted sample of 351 who were Gazetted officers, members of inspectorate, Noncommissioned officers and police constables of the National police service. The questionnaire return rate results were as below:

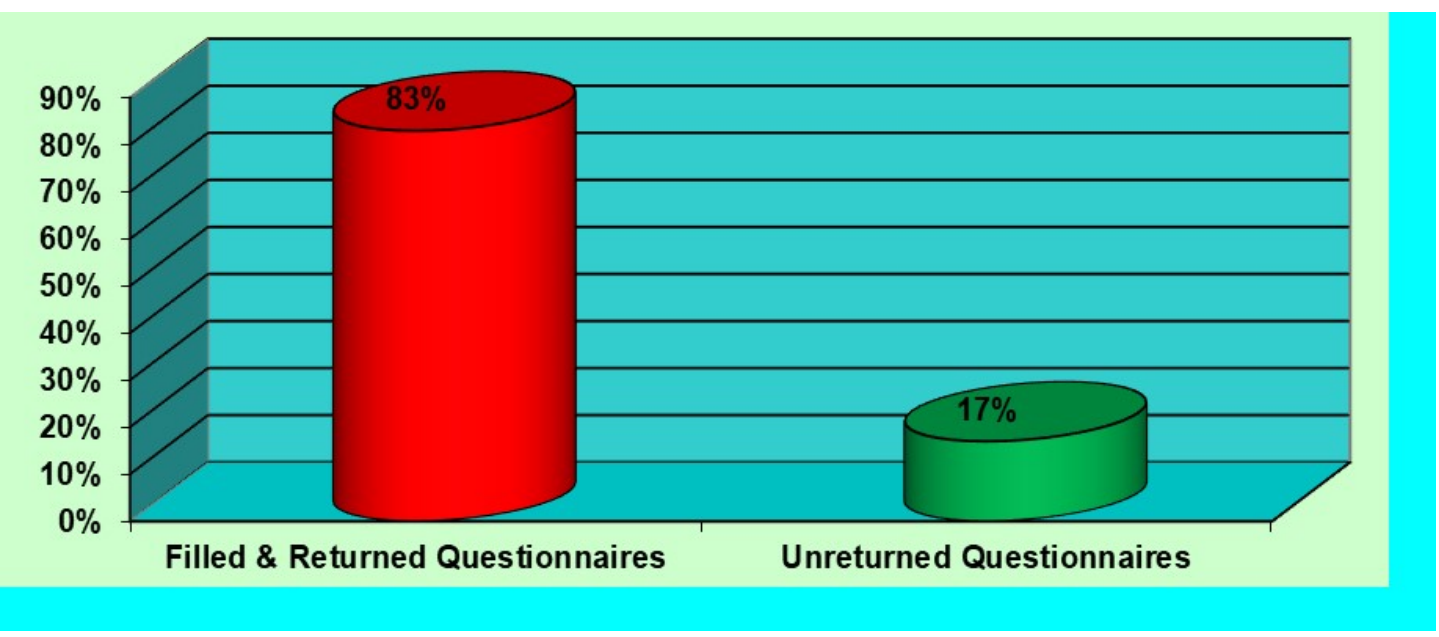

\section{Figure 1: Response Rate}

The results indicate that the questionnaires were administered to a targeted sample of 351 out of which, 293 $(83 \%)$ of the sampled respondents duly filled and returned the questionnaire. Failure to obtain $100 \%$ response rate was due to some questionnaire copies being misplaced while others were not fully filled $(17 \%$; $n=58)$. According to Mugenda and Mugenda (2003) a response rate of 50\% and above is adequate for analysis. Therefore $83 \%$ is commendable. This reasonable response rate was made a reality since the researcher made personal visits and regular phone calls to remind the respondents to complete the questionnaire promptly.

\subsubsection{Data Testing for Reliability}

The results of reliability analysis were majorly meant to correct inconsistencies arising from the data collection tool, which ensured that they bring out the true results of what is intended.

Table 1: Reliability Coefficients

\begin{tabular}{llc}
\hline Variables & Cronbach's Alpha & Number of Items \\
\hline Employee Performance & 0.841 & 06 \\
Performance Appraisal & 0.809 & 06
\end{tabular}

The reliability of the questionnaire was evaluated using test-retest technique where Cronbach's Alpha coefficient of reliability was computed to reveal internal consistency of the study questionnaire. Cronbach's Alpha Coefficients for the study variables were higher than the threshold of 0.7 meaning that the study questionnaire was reliable.

\subsubsection{Demographic characteristics of Respondents}

These were the respondents' details in regard to gender, age, position in the institution and length of service. This information was to assist the researcher to categorize the respondents in terms of exposure and experience. The findings were as follows: 


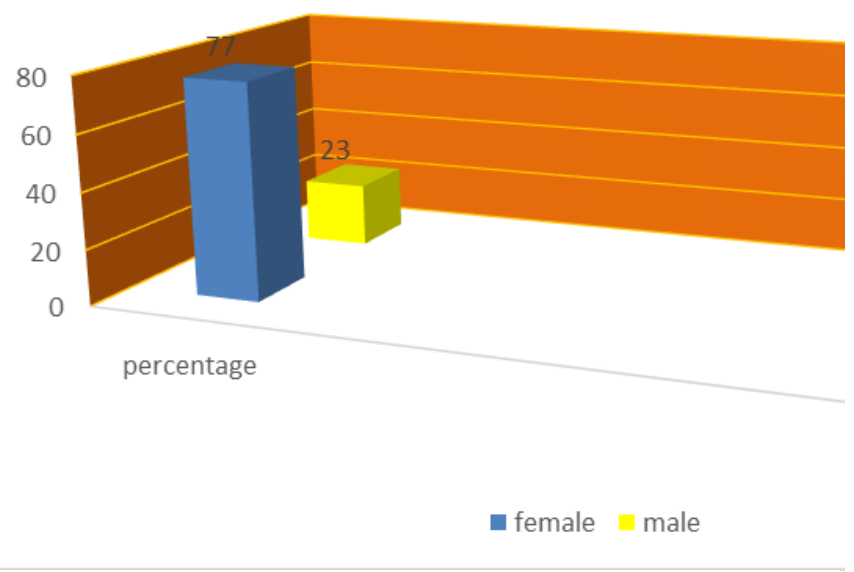

Figure 2: Gender

The study findings show that $77 \%(n=227)$ of the respondents were male while $23 \%(n=66)$ were female. It is inferred, therefore, that the majority of the respondents were male. Various studies on gender differences in employment point to the benefit of diversity mix as regards the zeal of male employees and the dedication and honesty of female employees combining to bring about improved performance (Dechev, 2017). It would be necessary to harness the talents that accrue from gender diversity in employment as a way of enhancing employee productivity in the National police Service.

Age of the respondents was considered to influence employee performance in the National police service and the findings were as follows:

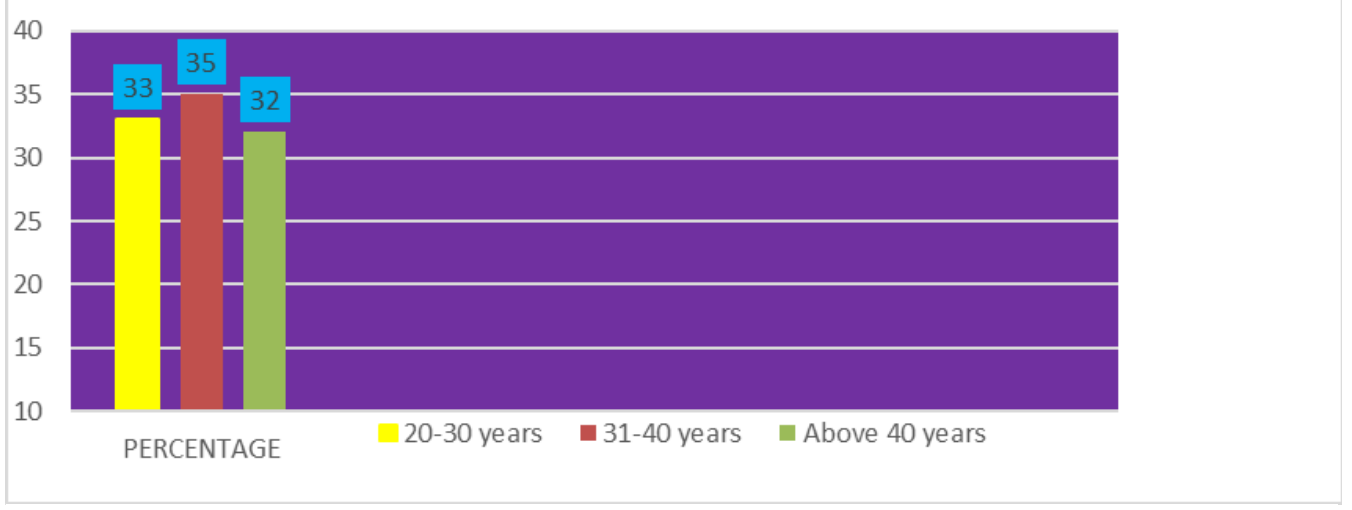

\section{Figure 3: Age bracket}

The results infer that majority (35\%) of the respondents were aged between 31 and 40 years, 33\% were aged between 20-30 years, and 32\% were aged more than 40years. It is evident that most of the respondents belonged to the younger age brackets hence the need to come up with appealing talent management strategies that would ensure that such employees are retained in the National Police Service. Such young employees are energetic, industrious and innovative with the desire to prosper and make it in life hence the need to craft employee management programmes that encourage talent management and by extension, their retention (Weinert, Maier \& Laumer, 2015). 
The level of education was also measured in this research. It was considered that the level of education of the respondents influences their productivity and commitment towards duties assigned culminating into the National Police Service enhanced performance. The findings were as follows:

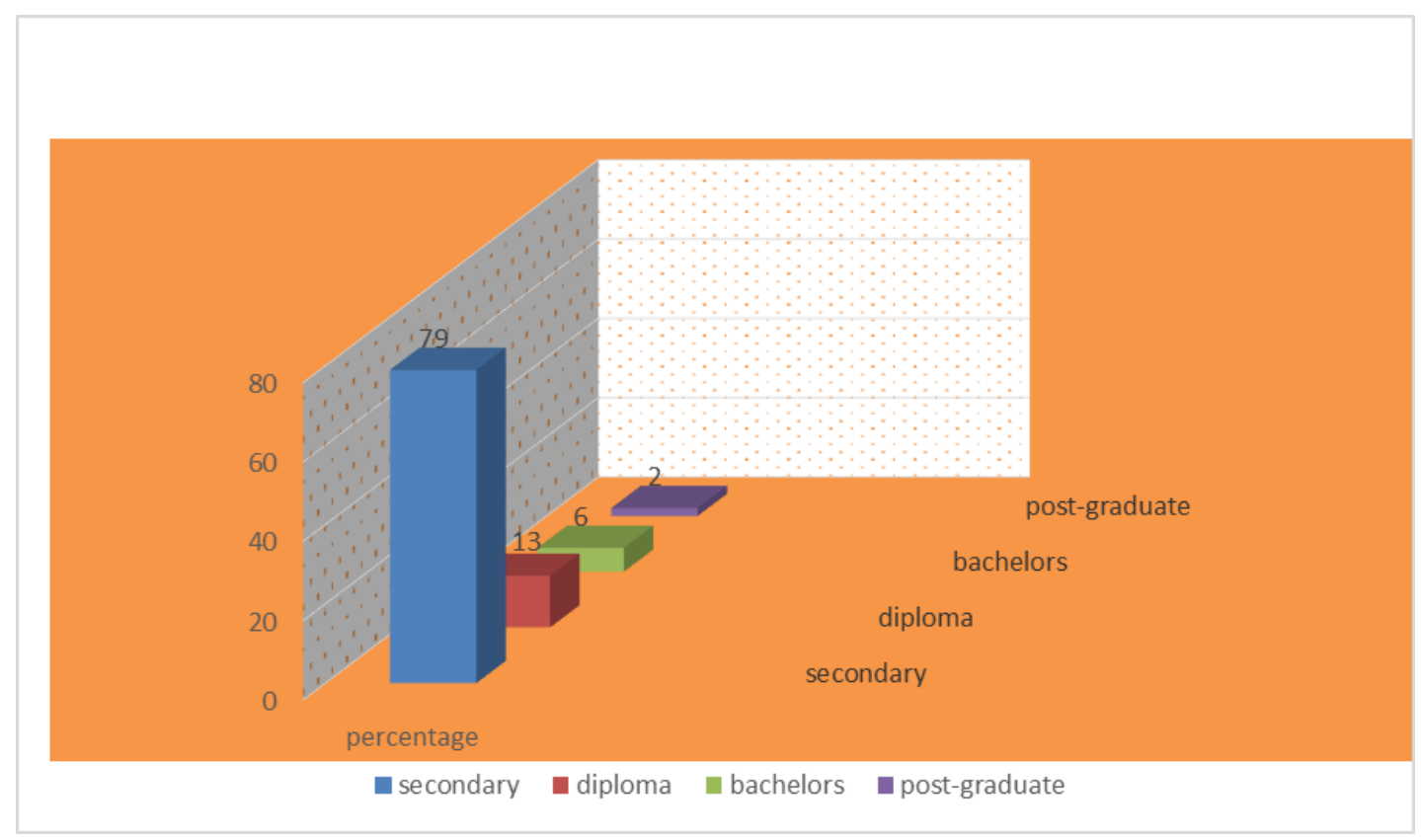

\section{Figure 4: Level of Education}

The findings imply that $79 \%$ of the respondents had attained secondary education, $2 \%$ had attained post graduate education, and $13 \%$ had attained diploma while 6 percent had bachelors' qualifications. It is inferred that $21 \%$ of the officers in the National police service had attained post-secondary education. This $79 \%$ is because secondary education is the entry level in the NPS (Possesses a minimum qualification of ' $\mathrm{D}+$ ' (Plus) in the Kenya Certificate of Secondary Education (KCSE) examination). However, they need to acquire college education in order to position themselves effectively to apply their talents for effective work performance. A study by Saba and Martin (2018) revealed that well educated employees are likely to remain in an organization long enough since most of them would want to see the contribution of their talents in the work place and may not be willing to let the gains made going to waste as a result of their exit from the organization.

The respondents were additionally requested to indicate their respective positions at work in the National Police Service and the results were as follows: 


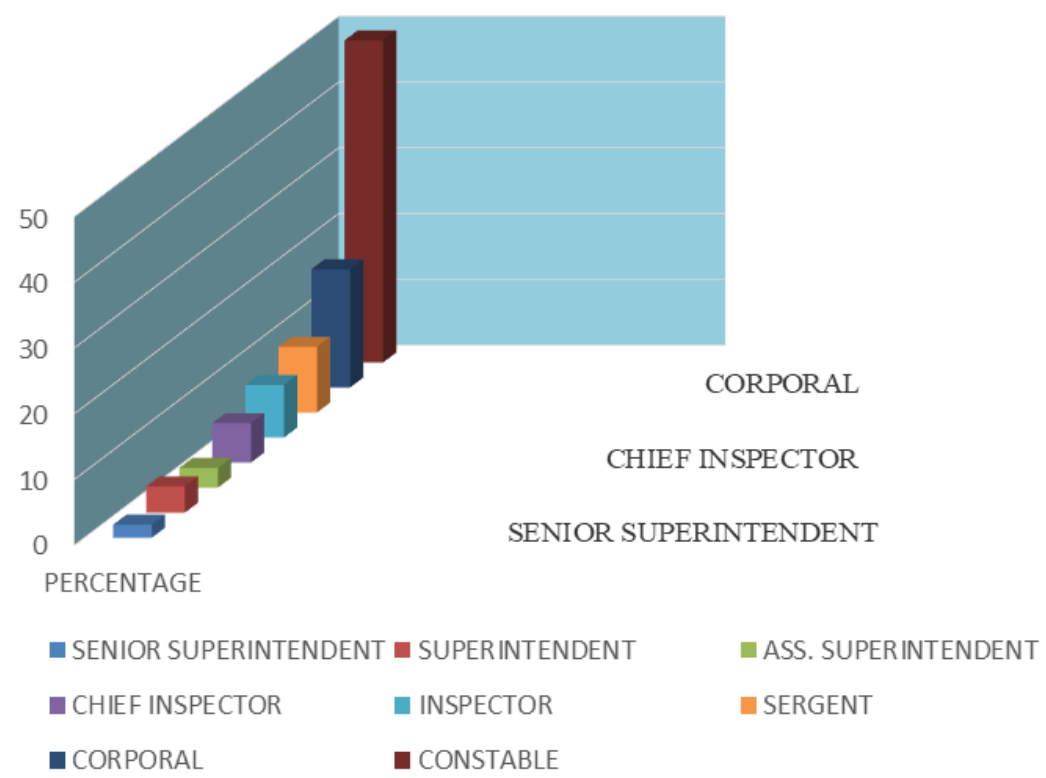

Figure 5: Service Rank

It is evident that most of the respondents were police constable who were $49 \%$. The second majority were Corporals $(18 \%)$ and sergeants $(10 \%)$ respectively. The high number of constables is because they play a critical front-line role in the prevention and detection of crime and the criminal justice system. Constables work in partnership on a day-to-day basis with local communities, stakeholders and colleagues in order to promote law and order, reduce the fear of crime, provide reassurance and build confidence to improve the quality of life for citizens. This calls for the need to concentrate talent management strategies among officers in the lower ranks given their role in the overall performance of the National police Service. As observed by Moore (2017), employees who are involved in the day-to-day operations of an organization form the backbone of that organization and every effort needs to be made to harness their talents as well as apply their diverse skills to the overall performance of the organization.

\subsubsection{Performance Appraisal and Employee Performance in the National Police Service}

Performance appraisal (PA) plays a central role in managing human resources in organizations. Therefore, it was important to establish how the appraisal in the national police service affects the performance of the employees. To measure the effects of appraisal on performance of the national police service, questionnaire in form of a Likert scale (1 to 5 ) was used. The respondents were therefore requested to indicate the extent to which they were in agreement with the following statements: 
Table 2: Performance Appraisal Descriptive Analysis

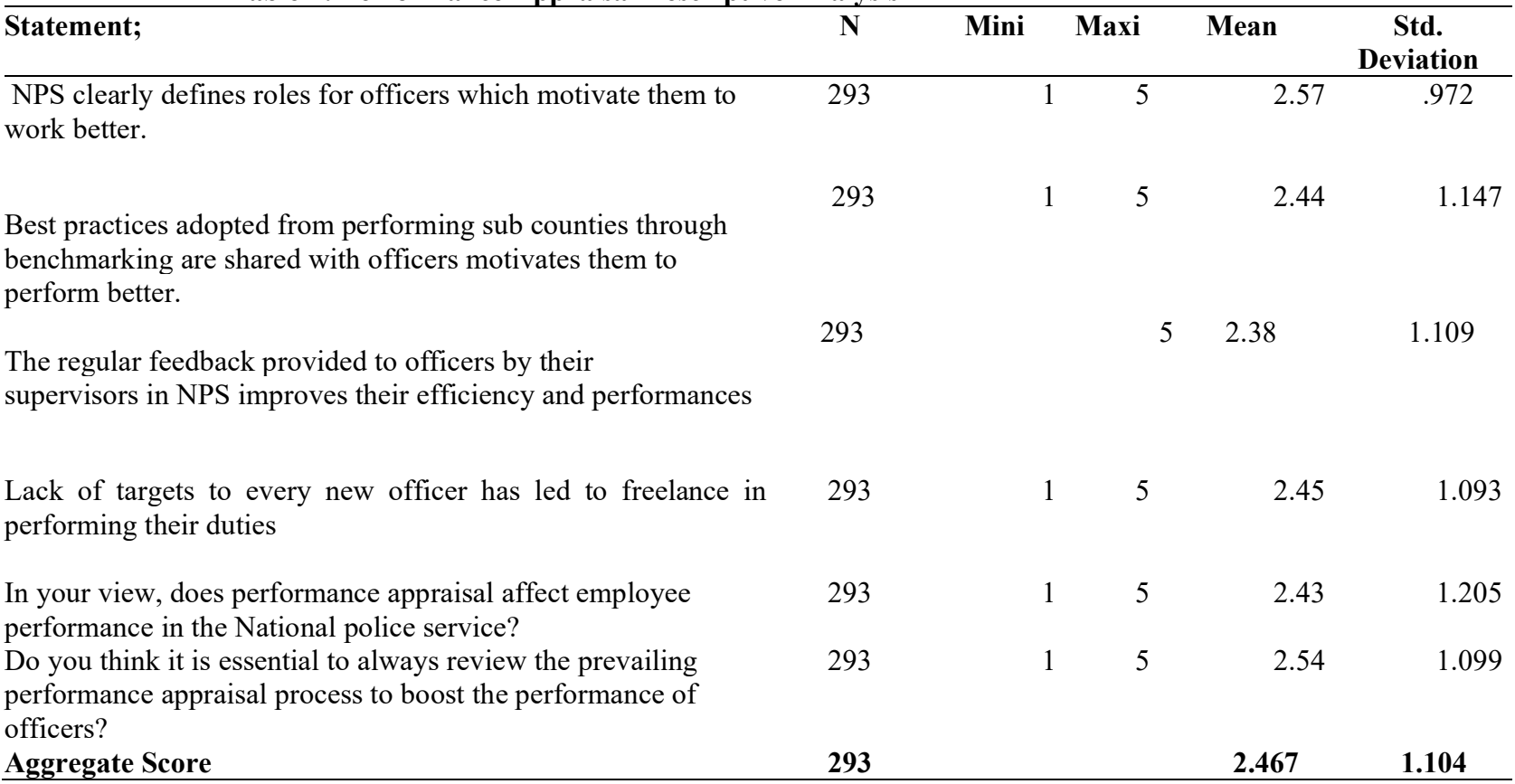

The average scores were $\mathrm{M}=2.468 ; \mathrm{SD}=1.104$. The standard deviation of 1.104 implied that there was a low variation on the respondents' selection of the listed aspects of performance appraisal. The mean value is averagely 2.5 , meaning that close to $50 \%$ of respondents were in agreement with the listed elements of performance appraisal. The study findings revealed that $51 \%$ of the respondents agreed that clearly defines roles for officers in NPS motivates officers to work better. Based on whether the organization benchmark with other performing sub counties, $49 \%$ of the respondents were of the view that the practice enables the service adopt best practices that motivates its officers to perform better. The results concur with a study by (Sahai and Srivastava (2012) who found that clear goal setting, which is an aspect of performance appraisal, provides a clear direction that enables the employees to work towards the organizational goals. Goal setting provides specific and measurable goals and hence provides clarity to the employees on what is expected out of them.

Lack of goal setting for example would make it difficult for assessing work performance. Lack of clear goals on what an officer should do at work could lead to ambiguity at work and freelance work performance which could be dangerous in the police service. It should be noted that the nature of police service is demanding and varied. It is also notable that the officers are empowered to act to their discretion given the nature of their work. Therefore, without clear goals the safety of the public would be at risk.

With clarity on what they are expected to the employees are able to plan and seek resources that would enable them achieve their goals. Marfiana (2019), argues that setting specific goals leads to higher performance. This is perhaps with clear goals leads to commitment of their attainment leading to strategic focus. Citing Locke, Marfiana (2019) observes that goal setting facilitate focus that whips the necessary knowledge and skills to achieve the goal hence improved performance. The implication is that setting clear goals helps the police officers achieve their organizational goals hence improved performance.

A study by Sahai and Srivastava (2012) revealed that successful performance appraisal is a function of clearly defined roles, achievable benchmarks, regular feedback on level of performance to inform corrective action and performance expectations are agreed upon much early before the start of the performance appraisal period to enable clear understanding of what is expected to achieve the set targets. 
Table 3: ANOVA

\begin{tabular}{llrrrrr}
\hline Model & & Sum of Squares & Df & Mean Square & F & \multicolumn{1}{c}{ Sig. } \\
\hline \multirow{2}{*}{1} & Regression & 133.369 & 4 & 33.342 & 39.114 & $.000^{\text {b }}$ \\
& Residual & 75.166 & 288 & .261 & & \\
& Total & 208.535 & 292 & & & \\
\hline
\end{tabular}

a. Dependent Variable: Employee Performance

b. Predictors: (Constant), Performance Appraisal

The ANOVA output reveals an $\mathrm{F}$ value of 39.114 at the level of significance of 0.000 . This implies that performance appraisal was a good predictor of employee performance in the National Police Service. Given the $\mathrm{p}$ value $=0.000$, the model was statistically significant in predicting employee performance in the National Police Service in Nairobi County.

Table 4: Model Summary

\begin{tabular}{ccccc}
\hline Model & $\mathrm{R}$ & $\mathrm{R}$ Square & Adjusted R Square & Std. Error of the Estimate \\
\hline 1 & $.300^{\mathrm{a}}$ & .293 & .271 & .51087 \\
\hline
\end{tabular}

a. Predictors: (Constant), Performance Appraisal

The Regression model revealed a coefficient of determination $\left(\mathrm{R}^{2}\right)$ with a value of 0.293 signifying that the independent variable (Performance Appraisal) accounted for 29.3\% of the variance witnessed in employee performance within the National Police service in Nairobi County, Kenya. All other factors that were not part of this study accounted for $70.7 \%$ of the variance in employee performance within the NPS in Nairobi County, which are otherwise explained by the Stochastic error term.

Table 5: Coefficients

\begin{tabular}{|c|c|c|c|c|c|}
\hline \multirow[t]{2}{*}{ Model } & \multicolumn{2}{|c|}{ Unstandardized Coefficients } & $\begin{array}{l}\text { Standardized } \\
\text { Coefficients }\end{array}$ & \multirow[t]{2}{*}{$\mathrm{T}$} & \multirow[t]{2}{*}{ Sig. } \\
\hline & B & Std. Error & Beta & & \\
\hline (Constant) & -.247 & .186 & & -1.330 & .185 \\
\hline Performance Appraisal & .772 & .042 & .723 & 18.220 & .000 \\
\hline
\end{tabular}

a. Dependent Variable: Employee Performance

Regression coefficients revel how much change in the dependent variable was a result of the individual independent variable while holding all other factors constant. From the study findings, while holding all other factors constant, a unit change in performance appraisal brought about 0.772 unit change in employee performance in the National police Service in Nairobi County, Kenya.

From the findings, it is clear that the performance appraisal is highly valued as a talent management tool for effective performance. This is not surprising as the key role for performance appraisal is to improve performance. In addition, the performance appraisal creates awareness among the employees by ensuring that they are aware of what they are expected to do and that what they do will be measured. Ayomikun, (2017) for example argued that the process starts by collaboratively establishing clear objectives for the employee followed by an action plan that that the employee is expected to execute to achieve the organizational as well as their own professional goals. Providing clear objectives for the employee is valuable guide that not only provide direction towards work performance but also provides the focus needed to enable the employee to prioritize key areas of their job description.

In addition, the collaborative approach in setting objectives helps to cultivate teamwork that enables the organization to achieve the set goals. According to Chiocchio, Grenier O’Neil, Savaria and Willms (2012) 
teamwork leads to collective efficacy. In relation to this study, collective efficacy is crucial for police performance. The nature of police work is one that requires that the officers work in teams and with their leaders to achieve organizational goals. This therefore means that a strategy that can enhance teamwork helps to develop collective efficacy works well in enhancing performance. Accordingly, collective efficacy creates social cohesion and trust with informal social control (Sergeant, 2012), thus enabling good working environment hence good performance. arguably spirit de corps is a life concept in police service thus through collaborative approaches the officers value interdependence that may be realized through team spirit.

High rating of Performance appraisal could also be because It provides information that can used to make administrative decisions to determine the reward or punishment of the officers. Van Dijk, D., Schodl, (2015), performance appraisal provides employees with feedback regarding their work performance that enables them to adjust to fit in the organizational expectation. In addition, being aware that they are being measured motivate them to work harder since their professional development dependent on what they score in appraisal.

A study by Sahai and Srivastava (2012) revealed that successful performance appraisal is a function of clearly defined roles, achievable benchmarks, regular feedback on level of performance to inform corrective action and performance expectations are agreed upon much early before the start of the performance appraisal period to enable clear understanding of what is expected to achieve the set targets.

\subsection{Conclusion}

Based on the study findings, the following conclusion is made;

The study objective sought to investigate the influence of performance appraisal strategy on employee performance in the National Police Service. Study findings from regression analysis revealed a statistically significant relationship between performance appraisal strategy on employee performance in the National Police Service. Consequently, the study concludes that performance appraisal strategy significantly influences employee performance in the National Police Service in Nairobi County, Kenya.

\subsection{Recommendations}

From the findings, it is clear that the performance appraisal is highly valued as a talent management tool for effective performance since it creates awareness among the employees by ensuring that they are aware of what they are expected to do and that what they do will be measured. The study recommends that all efforts towards performance appraisal start with an all-inclusive and collaborative step towards establishing clear objectives for the employee followed by an action plan that that the employee is expected to execute to achieve the organizational as well as their own professional goals. It is further recommended that employees are provided with clear objectives as a valuable guide that not only provide direction towards work performance but also provides the focus needed to enable the employee to prioritize key areas of their job description to enhance performance. Further still, employees need to be provided with feedback regarding their work performance that enables them to adjust to fit in the organizational expectation. In addition, being aware that they are being measured motivate them to work harder since their professional development dependent on what they score in appraisal.

\section{References}

Anderson, E. \& Aggerholm, E. (2018). Employee retention or company performance-The implied contribution of internal marketing activities.

Asava S. M. (2019). Talent management as a source of competitive advantage: a case study of symphony (K) ltd (Doctoral dissertation, University of Nairobi).

Baheshtiffar, M. (2016). Role of Career Competencies in Organization. European Journal of Economics Finance and Administrative Sciences, 42(1), 201-221.

Barney, J.B. (2017). Firm resources and sustained competitive advantage. Journal of Management, 17(1), 99120.

Beardwell, J. \& Claydon, T. (2017). Human Resource Management: A Contemporary Approach. 6th ed. Harlow: Pearson Education, pp. 161-195. 
Becker, G. S. (2016). Human Capital: A Theoretical and Empirical Analysis, With Special Reference to Education. New York: National Bureau of Economic Research.

Blumberg, B., Cooper, D., \& Schindler, P. (2018). Business Research Methods. New York: McGraw Hill Higher Education.

Burden, R., \& Proctor, T. (2016) "Creating a sustainable competitive advantage through Training", Team Performance Management, Vol.6 No.5-6 pp90-7

Cappelli, P. (2018). Talent management for the 21st century. Harvard Business Review, 86(3), 74-81.

Chandran, E. (2018). Research Methods: A Quantitative Approach with Illustrations from Christian Ministries. Nairobi: Daystar University

Chepkwony, Z. (2016). Effect of reward management practices on organizational commitment in state corporations in Kenya: a case study of kefri. Strategic Journal of Business \& Change Management, $3(3)$.

Collings, D. G., \& Mellahi, K. (2019). Strategic talent management: A review and research agenda. Human Resource Management Review, 19, 304-313.

Gakuru, B. W. (2016) Relationship between training practices and performance. A Survey of Companies listed on the NSE, Unpublished MBA project, University of Nairobi.

Gelens, J., Dries N., Hofmans, J., \& Pepermans, R. (2017). The role of perceived organizational justice in shaping the outcomes of talent management: a research agenda. Human Resource Management Review, 23(4), 341-353.

Ingram, T. (2016). Talent management in healthcare organizations-qualitative research results. Procedia Economics and Finance, 39, 339-346.

Javed G. \& Hussain, J. M. (2017). The impact of entrepreneurship education on succession in ethnic minority family firms. Education \& Training, 52 (8/9), 643-659.

Kehinde, J. S. (2016). Talent Management: Effect on Organizational Performance doi: 10.5296/jmr. v4i2. 937 URL: http://dx. doi. org/10.5296/jmr. v4i2. 937.

Kessler, G (2017) — Why the leadership bench never gets deeper”.Ten insights about executive. Talent development of people strategy, pp 25 (1)32.

Kireru, J. N. (2018). Challenges Affecting Implementation of Talent Management in State Corporations in - A Study of Kenya Broadcasting Corporation. Human Resource Management Review, 23 (6), 35-76.

Kermally, S. (2017). Developing and managing talent: How to match talent to a role and develop it to strength. London:

Kleiner, D. F. (2017). Designing effective performance appraisal systems. Work Study, 46 (6), 197-201.

Lambert, C., Kass, S., Piotrowski, C., \& Vodanovich, S, (2016). Impact factors on work-family balance. Initial support for border theory. Organiz. Dev. J, 24 (3), 64.

Mutunga, C. N. (2019). Factors that contribute to the level of employee engagement in the telecommunication industry in Kenya: a case study of Zain Kenya. Unpublished MBA Research Project, University of Nairobi.

Moore, F. (2017). Work-life balance: contrasting managers and workers in an MNC. Employee Relations, 29(4), 385-399. 
Nana, O. Y. (2017). Talent management: A Buddle of Hurdles. Public Police and Administration Research Paper, 3(8).

Ngesu, L., Wambua, L. B., Ndiku, J., \& Mwaka, M. (2018). Universities as learning organizations: Implications and Challenges. Education Research and Review, 3(9), 289-293.

Ng'ethe, J. M., Namusonge, G. S. \& Iravo, M. A. (2017). Influence of leadership style on academic staff retention in public universities in Kenya. International journal of business and social science, 3(21).

Rastgoo, M. (2016). Effects of repetitive transcranial magnetic stimulation on lower extremity spasticity and motor function in stroke patients. Disability and rehabilitation, 38(19), 1918-1926.

Ransley,P. (2009). Report of the National Task Force on Police Reforms. Nairobi: Government Printer

Ratna, R., Khanna, K., Jogishwar, N., Khattar, R., \& Agarwal, R. (2016). Impact of Learning Organization on Organizational Performance in Consulting Industry. International Journal on Global Business Management and Research, 2(2), 1-11.

Robinson, S. L. \& Morrison, E. W. (2017). The development of psychological contract breach and violation: A longitudinal study. Journal of Organizational Behavior, 21, 525-546.

Voslobana, R. I. (2017). The Influence of employee Performance on organizational growth- a managerial perspective. Selection and peer review under responsibility of Emerging Markets Queries in Finance and Business local organization.

Wandia, D. (2015). Employee engagement in Afya Savings \& Credit Co-operative Society (Sacco) limited (Unpublished MBA Thesis. University of Nairobi, Kenya)

Wangari, K. A. (2017). Talent management as a source of competitive advantage for Kenya Data Networks Ltd. The University of Nairobi.

Weinert, C;Maier, C; \& Laumer, S. (2015). The status of research on teleworking and an agenda for future research. International Journal of Management Reviews, 3(2): 113-130.

Wright, R. (2016). The Strategic Value of People: Human Resource Trends and Metrics. Ottawa: Conference Board of Canada.

Wright, P. \& Geroy, D. G. (2018). Changing the mindset: the training myth and the need for word-class performance. International Journal of Human Resource Management 12, 4, 586-600. 